\title{
Pengukuran Beban Kerja Menggunakan Metode Full Time Equivalent (FTE) Pada Divisi Proses PT. Delta Subur Permai
}

\author{
Moh Alyafi Dg. Matiro*‡, Raman S. Mau**, Abdul Rasyid ***, Fentje Abdul Rauf**** \\ $*, * *, * * *, * * * * J u r u s a n$ Teknik Industri, Fakultas Teknik, Universitas Negeri Gorontalo, Jl. Jenderal Sudirman \\ No.6 Kota Gorontalo, Indonesia 96128
}

(yapi.alyafi@gmail.com, ramanmau17@gmail.com, abdulrasyid@ung.ac.id, fentjerauf@ung.ac.id)

¥Penulis Koresponden; Moh Alyafi Dg. Matiro, Tel: 085242903372, yapi.alyafi@gmail.com

Diterima: 10.12.2020 Disetujui: 29.04.2021 Diterbitkan: 01.05.2021

\begin{abstract}
Abstrak- Kinerja karyawan merupakan salah satu faktor yang berpengaruh terhadap keberhasilan suatu organisasi maupun perusahaan. Dengan kinerja yang optimal dan sesuai prosedur maka akan diperoleh hasil yang optimal pula. Beban kerja yang terlalu berat atau terlalu ringan akan mengakibatkan terjadinya inefisiensi kerja. Beban kerja overload mengindikasikan bahwa jumlah pekerja yang dipekerjakan tidak sesuai dengan beban kerja yang diterima sehingga dapat menyebabkan kelelahan fisik maupun psikologis yang berakibat pada menurunnya produktivitas karena kelelahan bekerja. Tujuan penelitian ini adalah penentuan beban kerja menggunakan metode Full Time Equivalent (FTE) untuk dapat mengatasi penurunan produktivitas kerja. Untuk mendapatkan nilai FTE dari suatu proses kerja harus menggunakan perhitungan Work load Analisys dengan menggunakan persamaan total waktu aktivitas, Allowance, dan total waktu tersedia. Dari hasil penelitian ini di dapatkan hasil Work Load Analysis dalam menentukan beban kerja dan usulan jumlah karyawan yang ideal yakni ramp operator $144 \%$ (usulan 2 orang), Operator Sterilizer $65 \%$ (usulan 1 orang), tippler operator $84 \%$ (usulan 1 orang) pressing operator $44 \%$ (usulan 1 orang), Clarification operator $86 \%$ (usulan 1 orang) dan karnel operator $69 \%$ (usulan 1 orang).
\end{abstract}

Kata Kunci : Full Time Equivalent (FTE), Work Load Analysis, Allowance, Total Waktu Aktivitas, Total Waktu Tersedia.

\section{Measurement Of Work Load Using Full Time Equivalent (FTE) Method in The Processing Division of PT. Delta Subur Permai}

\begin{abstract}
With optimal performance and according to procedures, optimal results will also be obtained. Workloads that are too heavy or too light will result in work inefficiency. Overloaded workload indicates that the number of workers employed is not in accordance with the workload received, so it can cause physical and psychological fatigue which results in decreased productivity due to fatigue at work. The purpose of this research is to determine the workload using the Full Time Equivalent (FTE) method to overcome the decrease in work productivity. To get the FTE value of a work process, you must use the Work load Analysis calculation using the equation for total activity time, allowance, and total time available. From the results of this study, the results of the Work Load Analysis in determining the ideal workload and the proposed number of employees are obtained, namely the ramp operator of $144 \%$ (proposal of 2 people), $65 \%$ of Sterilizer Operators (suggestion of 1 person), $84 \%$ of operator tippler (suggestion of 1 person) pressing operator $44 \%$ (suggestion 1 person), Clarification operator $86 \%$.
\end{abstract}

Keywords : full time equivalent (FTE), Work Load Analysis,Allowance,Total Time, Total Availabe Time 


\section{Pendahuluan}

Sumber daya manusia dalam organisasi menjadi suatu bidang ilmu manajemen khusus yang dikenal dengan manajemen sumber daya manusia. Manajemen sumber daya manusia sangatlah penting dan memiliki banyak tantangan, sebab manusia memiliki karakteristik yang sangat berbeda dibandingkan dengan sumber daya yang lain. Manajemen sumber daya manusia merupakan program, aktivitas untuk mendapatkan sumber daya manusia, mengembangkan, memelihara dan mendaya gunakannya untuk mendukung organisasi mencapai tujuannya[1]. Ketersediaan SDM yang dibutuhkan untuk pelaksanaan tugas pada masa yang akan datang sangat penting untuk memastikan bahwa kegiatan perusahaan dapat terlaksana dengan baik[2].

Kinerja karyawan merupakan salah satu faktor yang berpengaruh terhadap keberhasilan suatu organisasi maupun perusahaan. Dengan kinerja yang optimal dan sesuai prosedur maka akan diperoleh hasil yang optimal pula.

Beban kerja yang dibebankan pada pekerja terjadi dalam tiga kondisi yaitu beban kerja normal (fit), beban kerja berlebih (overload) dan beban kerja yang terlalu rendah (underload) [3].

Full Time Equivalent (FTE) merupakan jumlah tenaga kerja (orang) yang dibutuhkan untuk melakukan/menyelesaikan serangkaian kegiatan tertentu pada periode tertentu. Perhitungan volume kerja diperoleh dengan mengalikan frekuensi dengan durasi dan jumlah sumber daya manusia yang dibutuhkan untuk melakukan pekerjaan tertentu[4]. Pekerjaan adalah suatu hubungan yang melibatkan dua pihak antara perusahaan dengan para karyawan/pekerja[5].

Beban kerja yang terlalu berat atau terlalu ringan akan mengakibatkan terjadinya inefisiensi kerja. Beban kerja overload mengindikasikan bahwa jumlah pekerja yang dipekerjakan tidak sesuai dengan beban kerja yang diterima sehingga dapat menyebabkan kelelahan fisik maupun psikologis yang berakibat pada menurunnya produktivitas karena kelelahan bekerja.

PT. delta subur permai adalah perusahaan yang bergerak dibidang produksi kelapa sawit, dan memiliki 4 divisi salah satunya adalah divisi proses yang memproduksi CPO dan karnel yang mempunyai 9 stasiun kerja melibatkan 10 operator mesin yang bekerja selama 7 jam yang dimana aktivitas dan metode kerja yang dikerjakan para operator tersebut berbeda. Divisi proses belum pernah melakukan perhitungan beban kerja, seingga diperlukan perhitungan beban kerja untuk mengetahui seberapa besar beban kerja pada divisi proses tersebut.

\section{Metode penilitian}

\section{1 ful time equivalent (FTE)}

Penelitian ini dimulai dengan pengumpulan data yang akan digunakan dalam penelitian ini. Data primer penelitian diantaranya adalah data tentang aktivitas kerja setiap stasiun kerja, waktu kerja untuk setiap aktivitas kerja utama serta waktu untuk aktivitas kerja pendukung. Selain itu terdapat jumlah frekuensi kerja serta durasi pekerjaan. Sedangkan data sekunder yang diperlukan pada penelitian ini adalah nama seluruh departemen pada perusahan, jumlah karyawan setiap departemen, alur produksi, mesin dan peralatan yang digunakan pada proses produksi. Data primer didapatkan melalui observasi langsung serta pengukuran waktu aktivitas kerja.

Pada tahap pengolahan data, dilakukan perhitungan beban kerja menggunakan metode full time equivalent, yaitu membandingkan jam kerja dengan waktu kerja efektif untuk menentukan karyawan ideal yang dibutuhkan dalam setahun.. Dari tahap pengolahan data akan dibuat presentasi beban kerja. Hasil dari pengolahan data tersebut kemudian diverifikasi, maka dapat menentukan jumlah karyawan yang optimal.

Full Time Equivalent adalah salah satu metode analisis beban kerja yang berbasiskan waktu dengan cara mengukur lama waktu penyelesaian pekerjaan kemudian waktu tersebut dikonversikan ke dalam indeks nilai FTE[6]. untuk mendapatkan nilai FTE dari suatu proses kerja adalah sebagai berikut [7]:

$F T E=\frac{(\text { Total waktu aktivitas }+ \text { Allowance })}{\text { Total waktu tersedia }}$

Dimana Total Waktu Aktivitas, Allowance Dan Total Waktu Tersedia dapat dihitung melalui persamaan sebagia berikut :

$>$ Total Waktu Aktivitas $=$ total waktu kegitanTotal waktu aktivitas $=$ total waktu kegitan.

$>$ Allowance $=$ Kelonggaran $\mathrm{x}$ Jumlah Hari Setahun x Jam Kerja Sehari.

$>$ Total waktu tersedia $=$ Jumlah hari dalam setahun X jumlah jam kerja sehari

FTE bertujuan untuk menyerdahanakan pengukuran kerja dengan mengubah jam kerja ke jumlah orang yang dibutuhkan untuk menyelesaikan pekerjaan tertentu[8].

Melakukan analisis beban kerja dengan FTE terdapat lima langkah yang perlu dilakukan yaitu[9].

> Menetapkan unit kerja beserta kategori tenaganya.

> Menetapkan waktu kerja yang tersedia selama satu tahun.

Data yang dibutuhkan untuk menetapkan waktu kerja dalam setahun adalah [10]: 
$>$ Hari kerja.

$>$ Cuti tahunan.

$>$ Pendidikan dan pelatihan

$>$ Hari libur nasional

$>$ Ketidak hadiran kerja

$>$ Waktu kerja

\section{Hasil dan pembahasan}

\section{1 pengolahan data}

Pengambilan data dilakukan dengan interview dan observasi di divisi proses PT Delta subur permai pada masing-masing jabatan. Data yang diambil terdiri dari data kegiatan pekerjaan tiap pekerja yang mengacu pada job description, durasi waktu pekerjaan, frekuensi pekerjaan, dan jenis kegiatan apakah kegiatan tersebut bersifat harian, mingguan, bulanan atau tahunan. Adapun jumlah karyawan tiap stasiun sebagai berikut.

Tabel 1 Jumlah karyawan pada divisi proses

\begin{tabular}{lc}
\hline Nama jabatan & Jumlah Karyawan \\
\hline Ramp Operaror & 1 \\
Operator Sterilizer & 1 \\
Operator tippler & 1 \\
Clarification operator & 1 \\
Pressing Operator & 1 \\
Karnel Operator & 1 \\
Power House Operator & 2 \\
Boiler Operator & 3 \\
\hline
\end{tabular}

\section{2 waktu kerja efektif}

Dalam pengambilan data waktu kerja efektif dalam penelitian ini menggunakan data sekunder berupa kalender kerja tahun 2020 yang dikeluarkan resmi oleh pemerintah republik Indonesia. Berdasarkan data kalender kerja tersebut maka selanjutnya dapat dilakukan perhitungan jumlah hari kerja efektif pada tahun 2020 yang ditujukan pada Tabel 2. Perhitungan jumlah hari kerja efektif pada Tabel 2 maka dapat dihitung pula jumlah jam kerja efektif dengan jam kerja per harisehinggah didapatkan jumlah jam kerja efektif tahun 2020 sebesar 1.953 jam.
Tabel 2 jumlah hari kerja efektif

\begin{tabular}{|c|c|}
\hline Keterangan & $\begin{array}{l}\text { Jumlah } \\
\text { hari }\end{array}$ \\
\hline Jumlah hari dalam setahun & 365 hari \\
\hline Jumlah hari cuti bersama(b) & 9 hari \\
\hline jumlah hari cuti individu(c) & 12 hari \\
\hline jumlah hari libur nasional (d) & 13 hari \\
\hline $\begin{array}{l}\text { jumlah hari minggu dalam setahun } \\
\text { (e) }\end{array}$ & 52 hari \\
\hline $\begin{array}{l}\text { Jumlah hari kerja efektif } \quad \text { (a-b-c- } \\
\text { d-e) }\end{array}$ & 279 hari \\
\hline
\end{tabular}

\subsection{Allowance/kelonggaran}

Pada kondisi aktual dilapangan seorang operator tidak akan mampu bekerja secara terus-menerus. Oleh karena itu diperlukan nilai faktor kelonggaran (allowance) yang merupakan waktu khusus untuk keperluan seperti kebutuhan pribadi, kebutuhan melepas lelah, dan kebutuhan lain yang diluar kendali operator.

Keterlambatan bisa disebabkan oleh berbagai faktor yang sulit dihindarkan atau bisa disebut unavoidable delay akan tetapi kadang kala ada juga faktor yang sebetulnya dapat dihindarkan. Dengan demikian keterlambatan yang besar tidak akan diperhatikan untuk menghitung waktu bakum [6].

pada penilitian kali ini, nilai faktor kelonggaran ditetapkan berdasarkan tabel ILO (international labour oraganitazion). Penilaian factor kelonggaran pada penilitian kali ini dilakukan oleh peneliti sendiri dan disetujui oleh pihak perusahaaan berdasarkan hasil pengamatan langsung di lapangan.

\subsection{Kegiatan Aktivitas Operator}

Untuk mengetahui aktivitas dari operator atau karyawan di divisi proses yaitu dengan menggunakan metode interview yaitu bertemu secara langsung dengan para operator/karyawan yang bersangkutan untuk memberikan informasi secara detail mengenai pekerjaan yang dilakukan setiap harinya, selain itu juga menggunakan arsip dari perusahaan tentang jobdes dari masing-masing karyawan. Berikut adalah aktifitas yang dilakukan pada masing" operator. 
Tabel 3. Allowance

\begin{tabular}{|c|c|c|c|c|c|c|c|c|c|c|c|c|c|}
\hline \multirow{2}{*}{ Nama jabatan } & \multicolumn{12}{|c|}{ Kategori allowance Berdasarkan tabel ILO } & \multirow{2}{*}{$\sum_{0}$} \\
\hline & A & $\mathrm{B}$ & $\mathrm{C}$ & $\mathrm{D}$ & $\mathrm{E}$ & $\mathrm{F}$ & $\mathrm{G}$ & $\mathrm{H}$ & $\mathrm{I}$ & $\mathrm{J}$ & $\mathrm{K}$ & $\mathrm{L}$ & \\
\hline Ramp Operaror & 5 & 4 & 2 & 0 & 0 & 0 & 0 & 0 & 2 & 1 & 4 & 2 & 20 \\
\hline Operator Sterilizer & 5 & 4 & 2 & 0 & 0 & 0 & 0 & 0 & 2 & 1 & 4 & 2 & 20 \\
\hline Operator tippler & 5 & 4 & 2 & 0 & 0 & 0 & 0 & 0 & 2 & 1 & 4 & 2 & 20 \\
\hline Clarification operator & 5 & 4 & 2 & 0 & 0 & 0 & 5 & 2 & 5 & 4 & 1 & 2 & 30 \\
\hline Pressing Operator & 5 & 4 & 2 & 0 & 0 & 0 & 0 & 2 & 5 & 4 & 1 & 2 & 25 \\
\hline Karnel Operator & 5 & 4 & 2 & 0 & 0 & 0 & 0 & 2 & 5 & 4 & 1 & 2 & 25 \\
\hline
\end{tabular}

Tabel 4. Kegiatan Ramp opertor

\begin{tabular}{|c|c|c|c|c|c|c|}
\hline kegiatan & periode & $\begin{array}{l}\text { Durasi } \\
\text { (menit) }\end{array}$ & Frek & $\begin{array}{l}\text { Jumlah } \\
\text { SDM }\end{array}$ & $\begin{array}{l}\text { Konversi } \\
\text { dalam } \\
\text { setahun }\end{array}$ & $\begin{array}{c}\text { Beban kerja } \\
\text { (orang-Menit ) }\end{array}$ \\
\hline $\begin{array}{l}\text { Menyiapkan lori yang } \\
\text { siap dimasukan TBS }\end{array}$ & harian & 8 & 4 & 1 & 279 & 8928 \\
\hline $\begin{array}{l}\text { Melakukan pengisian } \\
\text { TBS ke dalam Lori }\end{array}$ & harian & 19 & 16 & 1 & 279 & 84816 \\
\hline $\begin{array}{l}\text { Mengangkat } \\
\text { brondolan/buah yang } \\
\text { jatuh di lantai }\end{array}$ & harian & 24 & 2 & 1 & 279 & 13392 \\
\hline $\begin{array}{l}\text { Memindahkan lori } \\
\text { yang siap di rebus } \\
\text { dalam sterilizer }\end{array}$ & harian & 6 & 20 & 1 & 279 & 33480 \\
\hline Pembersihan stasiun & harian & 16 & 1 & 1 & 279 & 4464 \\
\hline \multicolumn{6}{|c|}{ Beban kerja unit perhari } & 145080 \\
\hline
\end{tabular}

Tabel 5. Kegiatan Sterilizer

\begin{tabular}{|l|l|c|c|c|c|c|}
\hline \multicolumn{1}{|c|}{ kegiatan } & periode & $\begin{array}{c}\text { Durasi } \\
\text { (menit) }\end{array}$ & Frek & $\begin{array}{c}\text { Jumlah } \\
\text { SDM }\end{array}$ & $\begin{array}{c}\text { Konversi } \\
\text { dalam } \\
\text { setahun }\end{array}$ & $\begin{array}{c}\text { Beban kerja } \\
\text { (orang-Menit })\end{array}$ \\
\hline $\begin{array}{l}\text { Membuka pintu } \\
\text { rebusan }\end{array}$ & harian & 7 & 4 & 1 & 279 & 7812 \\
\hline $\begin{array}{l}\text { Memasukan lori } \\
\text { kedalam rebusan }\end{array}$ & harian & 7 & 4 & 1 & 279 & 7812 \\
\hline $\begin{array}{l}\text { Menutup pintu } \\
\text { rebusan }\end{array}$ & harian & 7 & 4 & 1 & 279 & 7812 \\
\hline Mengisi log sheet & harian & 1 & 16 & 1 & 279 & 4464 \\
\hline $\begin{array}{l}\text { Menetapkan siklus } \\
\text { waktu rebusan }\end{array}$ & harian & 5 & 4 & 1 & 279 & 5580 \\
\hline Membuka valve & harian & 3 & 12 & 1 & 279 & 10044 \\
\hline Pembersihan stasiun & harian & 25 & 1 & 1 & 279 & 6975 \\
\hline $\begin{array}{l}\text { Pembersihan bagian } \\
\text { dalam masing masing } \\
\text { rebusan }\end{array}$ & harian & 264 & 1 & 1 & 12 & 3168 \\
\hline
\end{tabular}


Tabel 6. Kegiatan Operator Tippler

\begin{tabular}{|l|c|c|c|c|c|c|}
\hline \multicolumn{1}{|c|}{ kegiatan } & periode & $\begin{array}{c}\text { Durasi } \\
\text { (menit) }\end{array}$ & Frek & $\begin{array}{c}\text { Jumlah } \\
\text { SDM } \\
\text { dalam } \\
\text { setahun }\end{array}$ & $\begin{array}{c}\text { Keban kerja } \\
\text { (orang- } \\
\text { Menit) }\end{array}$ \\
\hline $\begin{array}{l}\text { Mengambil lori dan } \\
\text { memasukan kedalam tippler }\end{array}$ & harian & 6 & 6 & 1 & 279 & 10044 \\
\hline $\begin{array}{l}\text { Menuangkan isi Lori } \\
\text { kedalam conveyor }\end{array}$ & harian & 13 & 16 & 1 & 279 & 58032 \\
\hline $\begin{array}{l}\text { Mengisi log sheet } \\
\text { harian }\end{array}$ & 0.24 & 32 & 1 & 279 & 45.46 \\
\hline $\begin{array}{l}\text { Membersihkan area } \\
\text { stasiun }\end{array}$ & 30 & 1 & 1 & 279 & 8370 \\
\hline \multicolumn{2}{|c|}{ Beban kerja unit perhari } \\
\hline
\end{tabular}

Tabel 7 . Kegiatan pressing operator

\begin{tabular}{|c|c|c|c|c|c|c|}
\hline kegiatan & periode & $\begin{array}{l}\text { Durasi } \\
\text { (menit) }\end{array}$ & Frek & $\begin{array}{l}\text { Jumlah } \\
\text { SDM }\end{array}$ & $\begin{array}{l}\text { Konversi } \\
\text { dalam } \\
\text { setahun }\end{array}$ & $\begin{array}{c}\text { Beban kerja } \\
\text { (orang-Menit) }\end{array}$ \\
\hline $\begin{array}{l}\text { Menyalakan panel } \\
\text { stasiun }\end{array}$ & harian & 1 & 1 & 1 & 279 & 279 \\
\hline $\begin{array}{l}\text { Mengisi buah } \\
\text { kedalam } \\
\text { digester }\end{array}$ & harian & 10 & 1 & 1 & 279 & 2790 \\
\hline $\begin{array}{l}\text { pengecekan } \\
\text { tempratur } \\
\text { orasional digester }\end{array}$ & harian & 0.4 & 7 & 1 & 279 & 781.2 \\
\hline $\begin{array}{l}\text { Pengecekan ampere } \\
\text { digester } \\
\text { tiap jam }\end{array}$ & harian & 0.23 & 7 & 1 & 279 & 449.19 \\
\hline $\begin{array}{l}\text { Memberhentikan } \\
\text { inclined bunch } \\
\text { conveyor apabilaisi } \\
\text { digester telah } \\
\text { mencapai } 3 / 4 \text { dari } \\
\text { volume total }\end{array}$ & harian & 0.3 & 10 & 1 & 279 & 837 \\
\hline $\begin{array}{l}\text { Mengatasi } \\
\text { tersumbatnya } \\
\text { digester }\end{array}$ & harian & 8 & 3 & 1 & 279 & 6696 \\
\hline $\begin{array}{l}\text { Mengosongkan isi } \\
\text { press }\end{array}$ & harian & 10 & 3 & 1 & 279 & 8370 \\
\hline $\begin{array}{l}\text { Membersihkan area } \\
\text { stasiun }\end{array}$ & harian & 8 & 1 & 1 & 279 & 2232 \\
\hline \multicolumn{6}{|c|}{ Beban kerja unit perhari } & 22434.39 \\
\hline
\end{tabular}


Tabel 8 . Kegiatan clarification operator

\begin{tabular}{|c|c|c|c|c|c|c|}
\hline kegiatan & periode & $\begin{array}{l}\text { Durasi } \\
\text { (menit) }\end{array}$ & Frek & $\begin{array}{l}\text { Jumlah } \\
\text { SDM }\end{array}$ & $\begin{array}{l}\text { Konversi } \\
\text { dalam } \\
\text { setahun }\end{array}$ & $\begin{array}{c}\text { Beban kerja } \\
\text { (orang-Menit ) }\end{array}$ \\
\hline Mengjalankan mesin & Harian & 1 & 1 & 1 & 279 & 279 \\
\hline Mengisi log sheet & Harian & 1 & 7 & 1 & 279 & 1953 \\
\hline $\begin{array}{l}\text { Pengecekan vibrating } \\
\text { screen }\end{array}$ & Harian & 6 & 1 & 1 & 279 & 1674 \\
\hline $\begin{array}{l}\text { Pengecekan tempratur } \\
\text { crude oil tank }\end{array}$ & Harian & 2 & 6 & 1 & 279 & 3348 \\
\hline $\begin{array}{l}\text { Pemeriksaan pompa pada } \\
\text { crude oil tank agar } \\
\text { berfungsi dengan baik }\end{array}$ & Harian & 4 & 1 & 1 & 279 & 1116 \\
\hline $\begin{array}{l}\text { Pengecekan kebocoran } \\
\text { pada pipa dan fitings } \\
\text { pada crude oil tank }\end{array}$ & Harian & 3 & 2 & 1 & 279 & 1674 \\
\hline $\begin{array}{l}\text { Pembersihan crude oil } \\
\text { tank } \\
\text { secara menyeluruh }\end{array}$ & Tahunan & 130 & 1 & 1 & 1 & 130 \\
\hline $\begin{array}{l}\text { Membuang pasir buangan } \\
\text { sand cyclone secara rutin }\end{array}$ & Harian & 9 & 3 & 1 & 279 & 7533 \\
\hline menyetel steam & Harian & 5 & 4 & 1 & 279 & 5580 \\
\hline $\begin{array}{l}\text { Pengecekan tempratur } \\
\text { continuous settling tank }\end{array}$ & Harian & 2 & 6 & 1 & 279 & 3348 \\
\hline $\begin{array}{l}\text { Pembersihan continuous } \\
\text { settling tank }\end{array}$ & Tahunan & 134 & 1 & 1 & 1 & 134 \\
\hline $\begin{array}{l}\text { Pengecekan tempratur } \\
\text { sludge tank }\end{array}$ & Harian & 1 & 6 & 1 & 279 & 1674 \\
\hline $\begin{array}{l}\text { Pemersihan sludge tank } \\
\text { secara menyeluruh }\end{array}$ & Tahunan & 126 & 1 & 1 & 1 & 126 \\
\hline $\begin{array}{l}\text { Pengecekan tempratur } \\
\text { sludge buffer tank }\end{array}$ & Harian & 3 & 6 & 1 & 279 & 5022 \\
\hline $\begin{array}{l}\text { Pembersihan sludge } \\
\text { buffer } \\
\text { tank secara menyeluruh }\end{array}$ & Tahunan & 120 & 1 & 1 & 1 & 120 \\
\hline $\begin{array}{l}\text { Pembersihan nosel dari } \\
\text { centrifuge }\end{array}$ & Harian & 20 & 3 & 1 & 279 & 16740 \\
\hline $\begin{array}{l}\text { Mengirim minyak ke } \\
\text { storage }\end{array}$ & Harian & 1 & 1 & 1 & 279 & 279 \\
\hline Pembersihan area stasiun & Harian & 37 & 2 & 1 & 279 & 20646 \\
\hline \multicolumn{6}{|c|}{ Beban kerja unit perhari } & 65796 \\
\hline
\end{tabular}


Tabel 9 . Kegiatan Nut and karnel Operator

\begin{tabular}{|c|c|c|c|c|c|c|}
\hline kegiatan & periode & $\begin{array}{r}\text { Durasi } \\
\text { (menit) }\end{array}$ & Frek & $\begin{array}{l}\text { Jumlah } \\
\text { SDM }\end{array}$ & $\begin{array}{l}\text { Konversi } \\
\text { dalam } \\
\text { setahun }\end{array}$ & $\begin{array}{c}\text { Beban kerja } \\
\text { (orang-Menit } \\
\text { ) }\end{array}$ \\
\hline $\begin{array}{l}\text { Menghidupkan panel } \\
\text { mesin }\end{array}$ & Harian & 1 & 1 & 1 & 279 & 279 \\
\hline $\begin{array}{l}\text { Mengatur damper fan dan } \\
\text { depericapper }\end{array}$ & Harian & 6 & 1 & 1 & 279 & 1674 \\
\hline $\begin{array}{l}\text { Mengeluarkan kotoran } \\
\text { yang } \\
\text { muncul di polishing drum }\end{array}$ & Harian & 1 & 28 & 1 & 279 & 7812 \\
\hline $\begin{array}{l}\text { Membersihkan Nut yang } \\
\text { berhamburan diatas } N u t \\
\text { hopper }\end{array}$ & Harian & 6 & 1 & 1 & 279 & 1674 \\
\hline $\begin{array}{l}\text { Mengontrol Nut hopper } \\
\text { agar } \\
\text { tidak penuh atau kosong }\end{array}$ & Harian & 2 & 6 & 1 & 279 & 3348 \\
\hline $\begin{array}{l}\text { Pembersihan area ripple } \\
\text { mill }\end{array}$ & Harian & 7 & 2 & 1 & 279 & 3906 \\
\hline Memonitoring loses karnel & Harian & 8 & 6 & 1 & 279 & 13392 \\
\hline $\begin{array}{l}\text { Pemeriksaan vibrating } \\
\text { screen } \\
\text { claybath }\end{array}$ & Harian & 3 & 1 & 1 & 279 & 837 \\
\hline $\begin{array}{l}\text { Pembersihan endapan } \\
\text { deposit } \\
\text { CaCO3 pada parit buangan }\end{array}$ & Harian & 15 & 1 & 1 & 279 & 4185 \\
\hline $\begin{array}{l}\text { Penggantian air } \\
\text { hydrocyclone }\end{array}$ & Harian & 6 & 1 & 1 & 279 & 1674 \\
\hline $\begin{array}{l}\text { Pemeriksaan tekanan } \\
\text { pompa } \\
\text { Hidrocyclone }\end{array}$ & Harian & 3 & 4 & 1 & 279 & 3348 \\
\hline $\begin{array}{l}\text { Pengecekan agar tidak ada } \\
\text { terjadinya kebocoran pada } \\
\text { gland packing pompa }\end{array}$ & Harian & 2 & 6 & 1 & 279 & 3348 \\
\hline $\begin{array}{l}\text { Mengacek tempratur } \\
\text { karnel silo }\end{array}$ & Harian & 3 & 6 & 1 & 279 & 5022 \\
\hline $\begin{array}{l}\text { Memastikan baskulator } \\
\text { padatan } \\
\text { dapat berputar tanpa ada } \\
\text { hambatan }\end{array}$ & Harian & 4 & 1 & 1 & 279 & 1116 \\
\hline \multicolumn{6}{|c|}{ Beban kerja unit perhari } & 51615 \\
\hline
\end{tabular}




\subsection{Perhitungan Work Load Analisys}

Untuk perhitungan pada masing-masing jabatan yaitu diantaranya dengan menggunakan ketentuanketentuan sebagai berikut.

1. Allowance $=$ kelonggaran $\mathrm{X}$ jumlah hari setahun X jam kerja sehari.

2. Total waktu aktivitas $=$ total waktu kegitan

3. Total waktu tersedia $=$ Jumlah hari dalam setahun X jumlah jam kerja sehari.

Sehingga dapat mengetahui berapa beban kerja dan jumlah ideal tenaga kerja dalam setahun dengan menggunakan rumus sebagai berikut [5].

\section{Perhitungan pada Ramp operator}

$>$ Allowance $=$ kelonggaran $\mathrm{X}$ jumlah hari setahun $\mathrm{X}$ jam kerja sehari

$=20 \% \times 279 \times 420$

$=23436$ menit dalam satu tahun

$>$ Total waktu aktivitas $=145080$ menit

$>$ Total waktu tersedia $=117180$ meniit

Sehingga:

$$
\begin{gathered}
\text { FTE }=\frac{(\text { Total waktu aktivitas }+ \text { Allowance })}{\text { Total waktu tersedia }} \\
F T E=\frac{(145080+23436)}{117180} \\
F T E=1,44 \\
F T E=144 \%
\end{gathered}
$$

Jadi beban kerja pada ramp operator sebesar 1,44 yang berarti total kebutuhan tenaga kerja pada posisi ini yaitu sejumlah 2 orang.

Pada bagian ini akan dilakukan pembahasan pada hasil pengolahan data yang dilakukan pada bagian sebelumnya, sehinggah hasil pengolahan data dapat mudah dipahami.

Setelah dilakuakn pengamatan menggunakan metode yang ada maka di dapatkan hasil dari setiap stasiun sebagai berikut.

\section{Ramp Operaror}

Standar beban kerja untuk satu orang yaitu 100\% sehinggah jika beban kerja melebihi standar maka jabatan tersebut di tambahkan karyawan untuk menyelesaikan beban kerja tersebut.Beban kerja pada operator loading ramp yaitu $144 \%$, untuk memenuhi beban kerja tersebut maka dibutuhkan 2 orang karyawan.Pada posisi ini terdapat 1 orang karyawan sehinggah perbandingan perhitungan belum sesuai dengan keadaan saat ini di perusahaan.

\section{Operator Sterilizer}

Standar beban kerja untuk satu orang yaitu $100 \%$ sehinggah jika beban kerja melebihi standar maka jabatan tersebut di tambahkan karyawan untuk menyelesaikan beban kerja tersebut.Beban kerja pada operator loading ramp yaitu $65 \%$, untuk memenuhi beban kerja tersebut maka dibutuhkan 1 orang karyawan.Pada posisi ini terdapat 1 orang karyawan sehinggah perbandingan perhitungan sudah sesuai dengan keadaan saat ini di perusahaan.

\section{Operator tippler}

Standar beban kerja untuk satu orang yaitu $100 \%$ sehinggah jika beban kerja melebihi standar maka jabatan tersebut di tambahkan karyawan untuk menyelesaikan beban kerja tersebut. Beban kerja pada operator loading ramp yaitu $87 \%$, untuk memenuhi beban kerja tersebut maka dibutuhkan 1 orang karyawan. Pada posisi ini terdapat 1 orang karyawan sehinggah perbandingan perhitungan sudah sesuai dengan keadaan saat ini di perusahaan.

\section{Pressing Operator}

Standar beban kerXja untuk satu orang yaitu $100 \%$ sehinggah jika beban kerja melebihi standar maka jabatan tersebut di tambahkan karyawan untuk menyelesaikan beban kerja tersebut. Beban kerja pada operator loading ramp yaitu $44 \%$, untuk memenuhi beban kerja tersebut maka dibutuhkan 1 orang karyawan. Pada posisi ini terdapat 1 orang karyawan sehinggah perbandingan perhitungan sudah sesuai dengan keadaan saat ini di perusahaan.

\section{Clarification operator}

Standar beban kerja untuk satu orang yaitu $100 \%$ sehinggah jika beban kerja melebihi standar maka jabatan tersebut di tambahkan karyawan untuk menyelesaikan beban kerja tersebut. Beban kerja pada operator loading ramp yaitu $86 \%$, untuk memenuhi beban kerja tersebut maka dibutuhkan 1 orang karyawan. Pada posisi ini terdapat 1 orang karyawan sehinggah perbandingan perhitungan Belum sesuai dengan keadaan saat ini di perusahaan.

\section{Nut and Karnel Operator}

Standar beban kerja untuk satu orang yaitu $100 \%$ sehinggah jika beban kerja melebihi standar maka jabatan tersebut di tambahkan karyawan untuk menyelesaikan beban kerja tersebut. Beban kerja pada operator loading ramp yaitu $69 \%$, untuk memenuhi beban kerja tersebut maka dibutuhkan 1 orang karyawan. Pada posisi ini terdapat 1 orang karyawan sehinggah perbandingan perhitungan sudah sesuai dengan keadaan saat ini di perusahaan. 
Setelah dilakukan analisa beban kerja pada operator proses produksi dan di dapatkan hasil sebagai berikut.

Tabel 10. Kebutuhan tenaga kerja

\begin{tabular}{lccc}
\hline $\begin{array}{c}\text { nama } \\
\text { jabatan }\end{array}$ & $\begin{array}{c}\text { jumlah } \\
\text { keban } \\
\text { kerja }\end{array}$ & $\begin{array}{c}\text { tenaga kerja } \\
\text { berdasarkan } \\
\text { perhitugan } \\
\text { (orang) }\end{array}$ & $\begin{array}{c}\text { jumlah } \\
\text { tenaga } \\
\text { kerja } \\
\text { aktual }\end{array}$ \\
\hline $\begin{array}{l}\text { Ramp } \\
\text { Operaror }\end{array}$ & $\begin{array}{c}144 \\
\text { Operator }\end{array}$ & 2 & 1 \\
$\begin{array}{l}\text { Sterilizer } \\
\text { Operator }\end{array}$ & $65 \%$ & 1 & 1 \\
tippler & $84 \%$ & 1 & 1 \\
$\begin{array}{l}\text { Clarificat } \\
\text { ion } \\
\text { operator }\end{array}$ & $87 \%$ & 1 & 1 \\
$\begin{array}{l}\text { Pressing } \\
\text { Operator }\end{array}$ & $44 \%$ & 1 & 1 \\
$\begin{array}{l}\text { Karnel } \\
\text { Operator }\end{array}$ & $69 \%$ & 1 & \\
\hline
\end{tabular}

\section{Penutup}

\subsection{Kesimpulan}

$>$ Dengan melakukan penelitian workload analisysperusahaan dapat menentukan berapa jumlah karyawan ideal untuk masing-masing jabatan dalam setiap tahunnya. Beban kerja yang terdapat pada perusahaan PT. Delta Subur Permai divisi bagian proses, beban kerja pada ramp operator $165 \%$, beban kerja pada Operator Sterilizer $65 \%$, beban kerja pada tippler operator $84 \%$, beban kerja pada pressing operator 44\%, beban kerja pada Clarification operator $86 \%$, beban kerja pada karnel operator $69 \%$.

$>$ Berdasarkan beban kerja tiap jabatan yang telah dihitung maka dapat diketahui usulan kebutuhan jumlah tenaga kerja dalam kebijakan rekruitmen mendatang. Adapun Usulan jumlah tenaga kerja ramp operator adalah 2 orang, Usulan jumlah Pekerja Operator Sterilizer adalah 1 orang, Usulan jumlah Pekerja tippler operator adalah 1 orang, Usulan jumlah Pekerja pressing operator jumlah Pekerja Clarification operator adalah 1 orang, Usulan jumlah Pekerja karnel operator adalah 1 orang.

4.2 Saran
Setelah dilakukan pengolahan data beban kerja metode FTE pada setiap jabatan departemen produksi unit betalactam, maka saran yang dapat diberikan adalah sebagai berikut ;

Perusahaan terus meneruskan menelitian beban kerja dengan metode FTE pada unit dan divisi lain yang ada di PT Delta Subur Permai.

$>$ Perusahaan harus melakukan peninjauan ulang dalam membuat kebijakan rekruitmen pekerja di tahun mendatang.

\section{Daftar Pustaka}

[1] A. A. Prima, “Analisis Beban Kerja Terhadap Tenaga Kerja Analis Kimia Dengan Metode Full Time Equivalent Di Divisi Technology Development Departemen R\&D-Analytical Development Pt Xyz,” J. Pasti, Vol. Xii, No. 2, Pp. 154-168.

[2] D. T. Wardanis, “Analisis Beban Kerja Tenaga Rekam Medis Rumah Sakit Bedah SurabayaMenggunakan Metode FTE," J. Adm. Kesehat. Indones., vol. 6, no. 1, p. 53, 2018, doi: 10.20473/jaki.v6i1.2018.53-60.

[3] T. Y. T. Kusuma and M. F. S. Firdaus, "Penentuan Jumlah Tenaga Kerja Optimal untuk Peningkatan Produktifitas Kerja (Studi Kasus: UD. Rekayasa Wangdi W)," Integr. Lab J., vol. 7, no. 2, pp. 26-36, 2019.

[4] P. Lestari and E. Trisyulianti, "Analisis Beban Kerja dan Kebutuhan Karyawan (Direktorat Operasional Kantor Pusat) PT Perkebunan Nusantara VIII," J. Manaj. dan Organ., vol. 9, no. 3, pp. 181-190, 2018, doi: 10.29244/jmo.v9i3.28223.

[5] A. Febriantoro, "Menentukan Kebutuhan Tenaga Kerja Dengan Metode FTE (Full Time Equivalent) Pada Pekerjaan Shutdown Di PT Patriatama Mandiri Makassar," pp. 30-36, 2019.

[6] Tridoyo and Sriyanto, “Analisis Beban Kerja Dengan Metode Full Time Equivalent Untuk Mengoptimalkan Kinerja Karyawan Pada PT Astra International Tbk-Honda Sales Operation Region Semarang," J. Undip, vol. 3, no. 2, pp. $1-8,2014$.

[7] N. Hudaningsih and R. Prayoga, "Analisis Kebutuhan Karyawan Dengan Menggunakan Metode Full Time Equivalent ( FTE ) Pada Departemen Produksi PT. Borsya Cipta Communica," J. Tambora, vol. 3, no. 2, pp. 98106, 2019.

[8] E. M. S. dan M. M. Darmawan1*, "Pengukuran Waktu Baku Dan Analisis Beban Kerja Pada Proses Filling Dan Packing Produk Lulur," $J$. ASIIMETRIK J. Ilm. Rekayasa Inov., vol. 2.1, 
Pengukuran Beban Beban Kerja Menggunakan Metode Full Time Equivalent (FTE) Pada Divisi ...

Janua, pp. 51-61, 2020.

[9] H. N. Anisa and H. Prastawa, "Analisis Beban Kerja Pegawai Dengan Metode Full Time Equivalent ( FTE ) ( Studi Kasus pada PT . PLN ( Persero ) Distribusi Jateng dan DIY )," J. Undip, pp. 1-8, 2019, [Online]. Available: https://ejournal3.undip.ac.id/index.php/ieoj/arti cle/download/22988/21028.
[10] W. S. Madiun and A. L. Kakerissa, "Analisis Beban Kerja Karyawan Bagian Produksi Dengan Menggunakan Metode Full Time Equivalent (Fte) Di Ud Roti Alvine," Arika, vol. 11, no. 2, pp. 89-96, 2017, doi: 10.30598/arika.2017.11.2.89. 